\title{
Family Social Support and Learning Achievement of Student with Special Needs in Junior High School Inclusive Class
}

\author{
Ni'matuzahroh Ni'matuzahroh \\ Fakultas Psikologi \\ Universitas Muhammadiyah Malang Malang, \\ Indonesia
}

\author{
Riskha Dianita Anggreani \\ Fakultas Psikologi \\ Universitas Muhammadiyah Malang Malang, \\ Indonesia
}

\begin{abstract}
What is expected from student with special needs in inclusive school differs from other student with special needs. They are expected to be able to adapt with their own ability. This will affect their learning outcome. Family social support is one of the factors affecting the learning outcome of Student with special needs. This research aims to answer the question of what the connection between family social support and the learning achievement of student with special needs in inclusive school is. This research uses a nonexperimental quantitative method using total sampling method to gather forty samples that there are. The result shows that there is a high significant positive connection between family Social support and learning achievement. It is shown by the $r$-value of 0,802 dan the $p$-value of 0,000 . A conclusion can be drawn that the higher the family support, the higher the learning achievement on student with special needs.
\end{abstract}

Keywords-family social support; student with special needs; learning achievement

\section{INTRODUCTION}

Children with special need whether if it's phyisical or mental, is usually called children with special needs. These children have unique characteristics differing them from normal children This particular circumstance demands an adequate understanding regarding the nature of children with specual needs. They tend to experience many psychological matters resulting from the disability the have and/or from the way the society response to their disability. They need special care and education from trained professionals for them to be able to unlock their full potential. This is due to their hindered physical, psychological, social, and cognitive ability. Children with special needs need to be recognized and identified from the group of normal children.

Children with special needs is a broad term used to describe children with unique disabilities. Those disabilities vary from ADHD, mental illness, social unableness, blindness, deafness, to autism[1]. This will cause a negative consequence to the functionin $\mathrm{g}$ of the child and their learning achievement in school. However, growing learning achievement is possible if the support from family and society is high. Factors affecting the learning achievement on children with special needscanbecategorizedexternaland internal. Internal factor comes from within the children meanwhile external factor comes from outside the children such as family[2]Parents function as a system to guide the child to live the more complex social world [3] If students want to reach their full potential at school, then their family must support them fully [4]. Parents must put their attention and supporting the effort of advancing their child's learning. According to Ahmed, Minnaert, Werf dan [5] faith, trust, and emotion are earned mostly from social support which supports achievement. If parentsdo notfullysupporttheir children, they wont be able to study very well and will cause negative effects to the learning achievment.

TABLE 1.FAMILY SUPPORT T-SCORE SCALE CALCULATION

\begin{tabular}{|c|c|c|c|}
\hline Cateogry & Interval & Frequency & Percentage $(\%)$ \\
\hline High & $>50$ & 17 & 42.5 \\
\hline Low & $<50$ & 23 & 57.5 \\
\hline
\end{tabular}


TABLE 2.LEARNING ACHIEVEMENT T-SCORE SCALE CALCULATION

\begin{tabular}{ccccc}
\hline Category & Interval & Frequency & Percentage (\%) \\
\hline High & & $>50$ & 18 & 45 \\
Low & & $<50$ & 22 & 55 \\
\hline & Total & & 40 & $100 \%$ \\
\hline
\end{tabular}

TABLE 3.CORRELATION BETWEEN FAMILY SUPPORT AND LEARNING ACHIEVEMENT OF CHILDREN WITH SPECIAL NEEDS

\begin{tabular}{ll}
\hline Correlation Coefficient $(\mathrm{r})$ & AnalysisIndeks \\
\hline Correlation Coefficient $(\mathrm{r})$ & 0,802 \\
Determination Coefficient (r2) & 0,643 \\
Mistake Probability & 0,05 \\
$P$ (Value significance) & 0,000 \\
\hline
\end{tabular}

that they can achieve what's possible for them.

Social support is not merely about giving help, but it is about the receiver's percepetion towards the help. Social support refers to comfort, concern, appreciation, or help received from an individual or group (Sarafino, 2008), function and quality of a relationship, such as the willingness to accept help or actually receiving help [6] Social support can also be seen from how much social contact is done by an individual to maintain relationship between him and sources intheenvironmentand has fouraspects: emotional support, reward, instrument, and informative[7] Operational concept of social support is preceived support which has two fundamental elements: a perceptionthat there are certain amount of people that can be counted on by someone else and the notion that the degree of satisfaction varies. Social support can affect both mental and physical helath through its effect on emotion, cognition, and behavior [5]. Good social support will give children a chance to interact with their surroundings. Family support is expected to make things better for the individual. Family has a role to determine sets of behaviors in certainsituations, especially for children with special need in inclusive school[1][8]. Family, especially parents, is the closes to children and the most important support for them [7] According to $\mathrm{Xu} \&$ John [9] active involvement and support from family has been identified as key elements to the success of inclusive educational program. Paul, (2011), saidthat parental support, students involvement, and help will increase achievement of children with special needs. Parental support is reated to social development and personality which will help increase academic aspect[8] Children that fee loved by their parents will have a high self-esteem, meanwhile children that don't get enough support from their surroundings will have more risk of feeling lonely. Good social support will help students to get through their hardships in school so
According to Giesen, Cavenaugh dan [10] the amount of support the children with special needs gets correlates positively with their learning achievement.

Support and acceptance from the family will create faith inside the children to learn and try new things and consequentially they will get new achievements. Learning achievement is the result earned by someone in a learning process isthe result someone has achieved in learning [11]This research aims to answer the question of what the connection between family support and the learning achievement of children with special needs in inclusive schoolis.

\section{METHOD}

This research uses correlational quantitative method between two variables. The populationused in this research is the forty parents of children with special needs from six inclusive junior high school in the city of Malang. This schools are SMP Muhammadiyah 2, SMP Negeri 21, SMP Negeri 18, SMP Plus Al Kautsar, SMP Sriwedari, and SMP Satu Atap.The sampling technique used in this research is total sampling. Independent variable in this research is family support meanwhile the dependent variable is learning achievement. The method of collection data using the Likertscale. The analysis method used is Pearsons' productmoment correlation technique. The purpose is to know the relationship between $\mathrm{X}$ and $\mathrm{Y}$.

\section{RESULT AND DISCUSSION}

The result shows that there are more subject who have low family support than who have high family support. It can be seen from this table 1 .

Based on the distributed scale, we gain data showing the fact that there are more subject with low family support rather than subject with high 
family support. Out of the forty subjects, only 17 that are categorized as having high family support, $42,5 \%$ out of the entire subject. Consequentially, subjects categorized as having low family support is at the number of $23,57,5 \%$ out of the subject total .

Table 2 shown that out of the fourty subjects, 18 are categorized as having high learning achievement, $45 \%$ out of the total. Meanwhile, 22 subject are categorized as having low learning achievement, $55 \%$ out of the total.

Based one the analysis result we know that the $r$ value is 0.802 with the $p$ value is 0.000 . In the significance level is 0,05 . This shows that there is positive and highly significant relationship between family support and learning achievement of children with special needs. This means that the higher the familly support, the higher the learning achievement will be and vice versa.

The $r 2$ value is 0,643 on the family support scale. This means that the influence of family support towards learning achievement is at the rate of $64,3 \%$. Meanwhile other influence is at the rate of $35,7 \%$.

\section{DISCUSSION}

Social support generally describe only the influence created by significatn others. Social support can come from anywhere, for example family[12] .Family, especially parents are the closest to te children. Parents are the one who know and understand aspects of their children better than anybody else. [13]said that the efectivity of child with special needs development program depended heavily on the participation and support from the family. One of the function of family is education. In this term, the role of the family is toteachthechidrenandtoget them formal education so that they can function properly in the society. Where one of the functions of the family is the function of education.Familysupport has the biggest contribution in helping children with special needs adjust their life[14]Attention and support from parents comes in many forms including emotional, reward, instrumental, and information support. An individual will feel more motivated if his family give him high support. $52,5 \%$ of the subject has high emotional support. Family can give emotional support in the from of warmth, love, care, sympathy, and trust.Confidence will grow if an individual gets reward support from his parents. Only $42,5 \%$ out of the total subject has high reward support. This kind of support can take in the form of positive assessment. An individual will feel like he is being cared for if he gets instrumental support from his family. Only 37,5\% of the total subject has high instrumental support. This kind of support can take in the form of lending help in doing tasks and providing a good environment for the individual. Individual will feel like the get the attention they need if his parents give him information support. Out of the total subject, only $45 \%$ has high information support. This kind of support can take in the form of advice, compliment, agreement, and feedback on what should be done. Therefore, parents' active participation is form of social support determining a child's growth.

Parents' role to guide and motivate their children is important in terms of the succes of their learning achievement[1] Support from parents will give confidence to the children with special needs to do new things so that they can achieve their goals. On the contrary, denial or little support can make them see themselves in low regard. This will cause them to be afraid of trying new things and because of that will hinder their gwoth. They will end up functioning unproperly in the society and will always need others to help.

This research proves that there is positive relationship between family support and learning achievement of children with special needs. This means the higher the support, the higher the learning achievement and vice versa. In this research, subject with low family support has low learning achievement. This could mean that subject with low learning achievement is caused by the lack of support from their family. In reality, parents tend to have little to no time at all in teaching their child. This affects the learning achievement. According to Ahmed, Minnaert, Werf and Kuyper the children won't be able to study well if the parents don't give the support children need. Therefore, serious support is needed from the parents so the children can achieve high learning achievement.[5]

To increase the level of learning achievement, high family support is needed. According to Afolabi showed that there is a strong meaningful relationship between parents' involvement and academic achievement and that parents' trust, hope, and experience are important matter to better the learning achievement.[15] This shows that parents nurturing can help better the academic and non-academic achivement of children with special needs. This is supported by to result of research done by Mohsin,saying that there is a positive relationship between parental support by using their own style of teaching and modifying the children behavior and the learning achievement of children with special needs.[16]It is because parents are the closest to the children. Children 
with special needs in inclusive school will be able to fulfill what is demanded of them with their parents' support.

The influence of family support towards learning achievement is $63,4 \%$ while the $35,7 \%$ rest of the are other factors. Theses other factors are categorized into external and internal factors. The internal factors include physiological factors, sensory condition, and intelligence. Meanwhile the external factors are family, school, and the society. In this term, family support is very important in building the children learning achievement. This shows in the result of this research. If students want to maximize their potential then they need full support from their parents [4]

\section{CONCLUSION}

Conclusion of this study isa highly significant and positive relationship between family support and learning achievement of children with special needs. This is shown by the result of the $r$ value at 0,831 and the $p$ value at 0,000 . The implication for parents are hoped to give full support to the children with special needs that made them can adjust to the society and grow with their own ability which will increase the learning achievement. Furthermore, it is advice for further research regarding learning achievement of children with special needs to connect it with different variable than this research. Those variables include, physiological factor, sensory condition, psychological factor and intelligence. Meanwhile for the external factors are school, peers, and society.

\section{REFERENCES}

[1] Ahmed, W., Minnaert, A., Werf, G., \& Kuyper, H. (2010). Perceived Social Support and Early Adolescents' Achievements : The Mediational Roles of Motivational Beliefs and Emotions. Journal Youth Adolescence. 39, 36-46.

[2] Afolabi, O.E. (2014). Parents' involvement in Inclusive Education : An Empirical Test for the Psychoeducational Development of Learners with Special Educational Needs. International Journal of Educational Administration and Policy Studies. 6(10), 196-208.

[3] Baron, R.A., \& Byrne, D. (2005). Psikologi Sosial (Ed. 10). Jakarta : Erlangga.

[4] Berns, R.M. (2007). Child, family, school, community: Socialization and support. Seventh Edition. California: Thomson Wadsworth.
[5] Cohen, S. (1988). Psychosocial Models of the Role of Social Support in the Etiology of Physical Disease. Health Psychology, 7, 269-297.

[6] Delphie, B. (2006). PembelajaranAnak Berkebutuhan Khusus dalam Setting Pendidikan Inklusi. Bandung : Refika Aditama.

[7] Desforges, A. (2003). The Impact of Parental Involvement, Parental Support and Family Education on Pupil achievements and Adjusments a Literature Review. Queens Printer.

[8] Efendi, M. (2006). Pengantar Psikopedagogik Anak Berkelainan. Jakarta : PT Bumi Aksara

[9] Giesen, J.M., Cavenaugh, B.S., Donnall, M.C. (2012). Academic Supports, Cognitive Disability and Mathematics Achievement for Visually Imparied Youth : a Multilevel Modeling Approach. International Journal of Special Education. 27 (1).

[10] Hallahan, D.P., \& Kauffman, J.M. (2006). Exceptional Learner : An Introduction to Special Education. Boston : Allyn and Bacon.

[11] Heward, W.L. (2003). Exceptional Children, An Introduction to Special Education. New Jersey: Merrill, Prentice Hall.

[12] Mangunsong, F. (2009). Psikologi dan Pendidikan Anak Berkebutuhan Khusus Jilid Kesatu. Jakarta : LPSP3 UI.

[13] Mohsin, M.N., Khan, T.M., Doger, A.H., \&Awan, A.S (2011). Role of Parents in Training of Children with Intellectual Disability.International Journal of Humanities and Social Science.1 (9).

[14] Paul, S.M. (2011). Outcomes of Students with Disabilities in a Developing Country : Tobago. International Journal of Special Education. 26 (3).

[15] Santrock, J.W. (2003). Adolescence Perkembangan Remaja. (Terj. B. Shinto). Jakarta : Erlangga.

[16] Sarafino, E.P. (2011). Health Psychology. Biopsychosocial Interaction (7 th Edition). United States of America : John Wiley \& Sons, inc.

[17] Sarason, I.G., Levine, H.M., Basham, R.B., Sarason, B.R. (1983). Assesing social support : The social support questionnaire. Journal of Personality and Social Psychology. 44(1). 127-139. Accesed on March, 32015 fromhttp://web.psych.washington.edu/research/sarason/ files/SocialSupportQuestionnaire.pdf.

[18] Schwarzer, R \& Knoll, N. (2007). Functional roles of social support within the stress and coping process : A theoretical and emprical overview. International Journal of Psychology. 42 (4), 243-252.

[19] Slameto. (2003). Belajar dan Faktor-Faktor yang Mempengaruhinya. Jakarta : Rineka Cipta.

[20] Smet, B. (1994). Psikologi Kesehatan. Jakarta : Grasindo.

[21] Smith, D. (2012). Sekolah Inklusif : Konsep dan Penerapan Pembelajaran. Bandung: Nuansa.

[22] Sugiyono. (2007).

MetodePenelitianKuantitatifKualitatifdan R\&D. Bandung :Alfabeta.

[23] Sutrisno, M. (1997). Psikologi Pendidikan. Jakarta : Rineka Cipta.

[24] Winkel, W.S. (1996). Psikologi Pengajaran. Yogyakarta : Media Abadi.

[25] Xu, Y \& Filler, J. (2008). Facilitating Family Involvement and Support for Inclusive Education. The School Community Journal.18 (2). 